\title{
Functional role of post-translational modifications of Sp1 in tumorigenesis
}

Wen-Chang Chang ${ }^{1,2,3,4,5^{*}}$ and Jan-Jong Hung ${ }^{1,2,3,4^{*}}$

\begin{abstract}
Specific protein 1 (Sp1), the first transcription factor to be isolated, regulates the expression of numerous genes involved in cell proliferation, apoptosis, and differentiation. Recent studies found that an increase in Sp1 transcriptional activity is associated with the tumorigenesis. Moreover, post-translational modifications of Sp1, including glycosylation, phosphorylation, acetylation, sumoylation, ubiquitination, and methylation, regulate Sp1 transcriptional activity and modulate target gene expression by affecting its DNA binding activity, transactivation activity, or protein level. In addition, recent studies have investigated several compounds with anti-cancer activity that could inhibit Sp1 transcriptional activity. In this review, we describe the effect of various post-translational modifications on Sp1 transcriptional activity and discuss compounds that inhibit the activity of Sp1.
\end{abstract}

\section{Introduction}

The transcription factor Sp1 (specificity protein 1) belongs to the family of Sp/KLF (Krüppel-like factor) transcription factors. It is the first transcription factor purified and cloned from mammalian cells [1]. The human Sp1 gene maps to 12q13.1 and encodes a protein of 785 amino acids. The protein contains an $\mathrm{N}$-terminal transactivation domain, which recruits the basal transcriptional machinery complex to the target promoter, and a C-terminal DNA binding domain, which contains three $\mathrm{Cys}_{2} \mathrm{His}_{2}$-type zinc finger DNA binding motifs required for recognizing GC-rich (GGGGCGGGG) promoter sequences [2]. Sp1 regulates thousands of genes, such as those encoding vascular endothelial growth factor (VEGF), $\mathrm{p} 21^{\mathrm{CIP} 1 / \mathrm{WAF} 1}, 12$ (S)-lipoxygenase, phosphatase 2A (PP2A), and Sp1 itself. Thus, Sp1 is important for a variety of physiological processes, including angiogenesis, cell cycle progression, inflammation, and senescence [3-6]. Dysregulation of Sp1 is observed in many cancers and neurodegenerative disorders. Sp1 gene knockout is embryonic lethal at the $11^{\text {th }}$ day of gestation [7].

Sp1 has been reported to affect the tumorigenesis of many cancer types by modulating the expression of its

\footnotetext{
* Correspondence: petehung@mail.ncku.edu.tw; wcchang@tmu.edu.tw 'Institute of Basic Medical Sciences, College of Medicine, National ChengKung University, Tainan 701, Taiwan

${ }^{2}$ Department of Pharmacology, College of Medicine, National Cheng-Kung University, Tainan 701, Taiwan

Full list of author information is available at the end of the article
}

target genes, which include oncogenes and tumor suppressor genes. A recent study demonstrated that both single nucleotide polymorphism (SNP) 285 and SNP 309 in MDM2 (murine double mutant 2) are found in breast cancer and can affect the binding of Sp1 to the MDM2 promoter [8]. In addition, the insulin-like growth factor (IGF) system plays an important role in the biology of breast cancer. A previous study revealed that caveolin-1 up-regulates IGF-1 receptor gene transcription in breast cancer cells via Sp1- and p53-dependent pathways [9]. A number of E2-responsive genes involved in nucleotide biosynthesis and cell cycle progression are dependent on estrogen receptor (ER)- $\alpha / \mathrm{Sp1}$ interactions [10]. Moreover, it was reported that phytoestrogen regulation of the vitamin D3 receptor promoter is regulated by Sp1. Finally, in the presence of the estrogen receptor antagonist ICI 182780, ER- $\alpha$ and histone deacetylases (HDACs) dissociate from $\mathrm{Sp} 1$, resulting in increased histone acetylation and the induction of p21 expression [11,12]. In lung cancer, we recently found that $\mathrm{Sp} 1$ accumulates in the early stage and then declines in the late stage, which is important for lung cancer cell proliferation and metastasis. Sp1 was required for lung tumor growth but it suppressed metastasis by inducing E-cadherin expression. The clinical implication of these results is that $\mathrm{Sp} 1$ inhibition is seemingly inappropriate for all patients with lung cancer ranging from stage I to IV [13]. In addition, the deregulation of DNA (cytosine-5-)-methyltransferase 1 (DNMT1) is associated with a gain in the transcriptional

\section{Biomed Central}


activation of $\mathrm{Sp} 1$ and a loss in the repression of p53. DNMT1 overexpression might result in the epigenetic alteration of multiple tumor suppressor genes and ultimately lead to lung tumorigenesis and poor prognosis [14]. The cytosolic phospholipases A2 (cPLA2) expression is regulated by $\mathrm{Sp} 1$ and c-Jun in lung cancer cells [15]. In colon cancer, HDAC inhibitors can induce cancer cell apoptosis by activating Krüppel-like factor 4, and Sp1/ Sp3 can increase the apoptotic sensitivity of colon cancers to histone deacetylase inhibitors [16]. In addition to the cancer types described here, Sp1 is implicated in other cancer types and in tumorigenesis by mediating the expression of many oncogenes [17-19].

\section{Effects of post-translational modifications of Sp1 on its transcriptional activity}

The involvement of Sp1 in the development of various cancer types is well known. The transcriptional activity of $\mathrm{Sp} 1$ is modulated by post-translational modifications that regulate $\mathrm{Sp} 1$ protein level, transactivation activity, and DNA binding affinity [20]. Here, we describe the
Sp1 modifications and their effects on Sp1 transcriptional activity as indicated in Figure 1.

\section{Phosphorylation}

There are 23 putative phosphorylation sites (from PhosphoSitePlus ${ }^{\circledR}$ ) among the 785 amino acids of Sp1. Many of these sites have been shown to positively or negatively affect Sp1 transcriptional activity by modulating Sp1's DNA binding affinity, transactivation activity, or total protein level in a manner dependent on the position of the residue or the condition of the cell [20].

\section{Effect on Sp1 DNA binding activity}

Sp1 is phosphorylated at Ser59 by cyclin A-cyclin dependent kinase (CDK). In in vitro and in vivo phosphorylation studies, cyclin A-CDK complexes can phosphorylate Sp1, and the phosphorylation site is located within the N-terminal region of the protein [21]. The DNA binding activity of Sp1 is elevated in cells overexpressing cyclin A [21]. How a phosphorylation site located in the $\mathrm{N}$-terminus of $\mathrm{Sp} 1$ affects the zinc finger

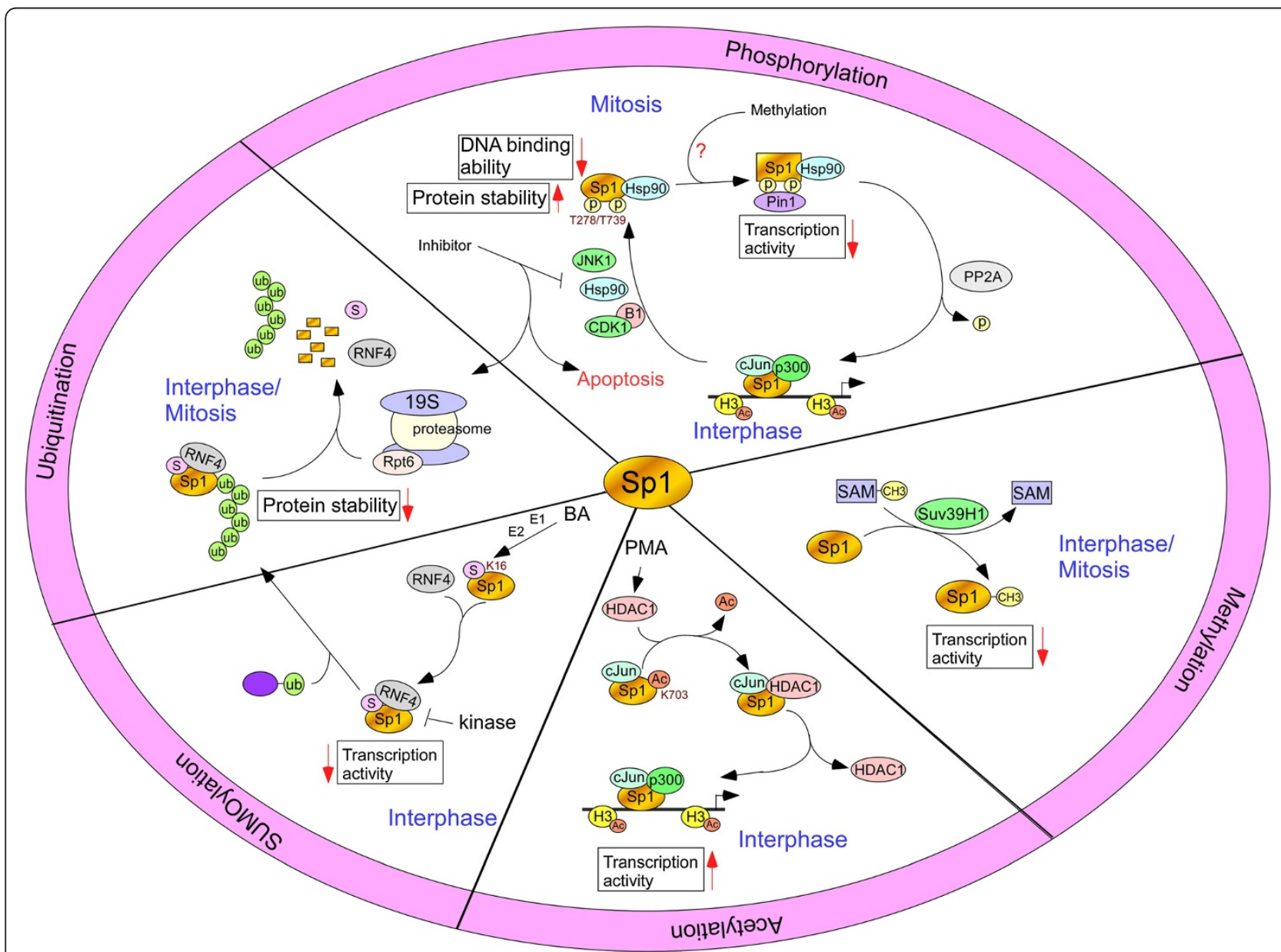

Figure 1 The schematic diagram illustrating that various modifications in Sp1 modulate its transcriptional activity. 
domains in the C-terminus of $\mathrm{Sp} 1$ is still unknown and needs further studies. We recently reported that $\mathrm{Sp} 1$ is a mitotic substrate of CDK1/cyclin B1 and is phosphorylated by CDK1/cyclin B1at Thr739. Phosphorylation of Sp1 reduces its DNA-binding ability and facilitates the chromatin condensation process during mitosis [22]. At the end of mitosis and the beginning of interphase, Sp1 is dephosphorylated by PP2A and returned to the chromatin. These results indicate that cancer cells use CDK1 and PP2A to regulate the movement of Sp1 in and out of the chromosomes during cell cycle progression. Sp1 is also phosphorylated at Thr668 by casein kinase II (CKII) to decrease its DNA binding activity. In addition, treatment of K562 cells with okadaic acid increases Sp1 phosphorylation and inhibits its DNA binding activity, suggesting that steady state levels of Sp1 phosphorylation are established by a balance between kinase and phosphatase activities [23]. However, phosphorylation of Sp1 at Thr668, Ser670, and Thr681 by protein kinase C zeta $(\mathrm{PKC}-\zeta)$ is required for Sp1-dependent plateletderived growth factor-D activation in response to angiotensin II [24]. Further studies are needed to explain why the phosphorylation of Sp1 in this region has different effects on Sp1 transcriptional activity.

\section{Effect on Sp1 transactivation activity}

Many of the phosphorylation sites shown in Table 1 could regulate the transcriptional activity of $\mathrm{Sp} 1$ by altering its interaction with other proteins, such as p300 and HDACs, which can positively or negatively regulates the Sp1 target genes.

\section{Effect on Sp1 protein stability}

Recent studies have shown several phosphorylation sites related to $\mathrm{Sp} 1$ protein stability. Sp1 is highly phosphorylated during mitosis. Phosphorylation of Sp1 by c-Jun Nterminal kinase 1 (JNK1) at Thr278/739 is important for the maintenance of Sp1 in daughter cells. JNK1 is also highly activated during tumorigenesis and correlates with Sp1 protein level. These results indicate that JNK1 activation is necessary to phosphorylate Sp1 and to shield Sp1 from the ubiquitin-dependent degradation pathway during mitosis in tumor cell lines [28]. In addition, heat shock protein 90 (HSP90) can interact with $\mathrm{Sp} 1$ during mitosis to alter the phosphorylation of Sp1 at Thr278/739 by JNK1 and increase Sp1 protein stability [39]. These results indicate that Hsp90 might interact with JNK1 and stabilize it during mitosis, and thereby enhance the phosphorylation of Sp1. Our recent studies indicate that phosphorylation of Sp1 at Thr739 increases its stability by preventing interaction with RING finger protein 4 (RNF4), thus shielding Sp1 from proteasome-dependent degradation [33]. However, the manner in which phosphorylated $\mathrm{Sp} 1$ is shielded from interaction with RNF4 needs to be clarified.

In addition, several phosphorylation sites of Sp1 have been probed, and their roles have been elucidated, but the detailed mechanism is still unknown. It was reported that Sp1 can be phosphorylated by ataxia telangiectasia mutated (ATM) at Ser101 under DNA damage conditions [25]. Sp1 with a Ser101Ala mutation is not significantly phosphorylated in response to damage, and it can not restore sensitivity to DNA damage [25]. These

Table 1 Post-translational modification of Sp1

\begin{tabular}{|c|c|c|c|c|}
\hline PTM & Modified sites & Modified enzymes & Functions & Ref. \\
\hline \multirow[t]{12}{*}{ Phosphorylation } & Ser59 & CDK2 & Increase Sp1 DNA binding activity & {$[21]$} \\
\hline & Ser101 & ATM & Involve in DNA damage and repair & {$[25]$} \\
\hline & $\underline{\text { Ser131 }}$ & DNA-PK & Upregulate expression of the HIV-1 Tat protein. & {$[26]$} \\
\hline & Thr266 & Ras-MAPK & Increase expression of apolipoprotein A-I & {$[27]$} \\
\hline & Thr278/739 & JNK1 & Increase Sp1 protein stability & {$[28]$} \\
\hline & Thr453/739 & P42/p44 MAPK & Enhance VEGF expression & {$[29]$} \\
\hline & & ERK1/2 & Repress PDGFR-a transcription & {$[30]$} \\
\hline & & ERK1/2 & Inhibit RECK expression and promote cell invasion & {$[31]$} \\
\hline & Ser641 & $\mathrm{PI} 3 \mathrm{~K} / \mathrm{PKC \zeta}$ & Increase luteinizing hormone receptor (LHR) transcription & {$[32]$} \\
\hline & Thr668 & CKII & Decreased Sp1 DNA binding acticity & {$[23]$} \\
\hline & Thr668/Ser670/Thr681 & PKC & Increase PDGF transcription & {$[24]$} \\
\hline & Thr739 & CDK1 & Decrease Sp1 binding activity & {$[22]$} \\
\hline Sumoylation & Lys16 & Sumo-1 & Enhance Sp1 degradation & {$[33,34]$} \\
\hline Methylation & ND & ND & Recruit Suv39H1 and HDAC1 to induce chromatin remodeling & {$[35]$} \\
\hline Acetylation & Lys703 & P300 & Recruit HDAC1 and p300 to the promoter of the 12(S)-lipoxygenase & {$[36]$} \\
\hline \multirow[t]{2}{*}{ Glycosylation } & Leu56/57 & ND & Sp1 degradation & {$[37]$} \\
\hline & Ser612/641/698/702, Thr640 & ND & Regulate transcriptional activity of Sp1 & [38] \\
\hline
\end{tabular}


results indicate that $\mathrm{Sp} 1$ is an ATM substrate that plays a role in the cellular response to DNA damage. Ser101 phosphorylation did not affect transcriptional activity from the Sp1 responsive promoter, but it did promote co-localization of Sp1 with ATM phosphorylated at Ser1981. These observations suggest that Sp1 phosphorylated at Ser101 might play a role in DNA repair at damage sites rather than functioning in transcriptional regulation, but further evidence is required to substantiate this possibility. The mechanism by which Sp1, phosphorylated at Ser101 by ATM, affects DNA damage needs to be elucidated. In addition, it was reported that EGF stimulation of apoA-I expression is mediated solely by the Ras-MAP kinase cascade and that enhanced activity of this pathway requires Sp1 with an intact phosphorylation site at Thr266 [27]. It was also shown that trichostatin A (TSA) causes marked phosphorylation of Sp1 at Ser 641 by PKC $\zeta$ in JAR and MCF-7 cells, indicating that phosphorylation of $\mathrm{Sp} 1$ by phosphatidylinositol 3-kinase (PI3K)/PKC $\zeta$ is critical for TSA-activated lutropin/choriogonadotropin receptor (LHR) gene expression [32]. It was also reported that $\mathrm{p} 42 / \mathrm{p} 44$ mitogenactivated protein kinase (MAPK) directly phosphorylates Sp1 at Thr453 and Thr739 in vitro and in vivo, and mutation of these sites to alanine decreases Sp1 transcriptional activity [29]. In addition, fibroblast growth factor 2 (FGF-2) stimulates Sp1 phosphorylation in an extracellular signal-regulated kinase (ERK) 1/2- but not p38-dependent manner, and enhances $\mathrm{Sp} 1$ recruitment to the plateletderived growth factor receptor alpha (PDGFR- $\alpha$ ) promoter region [30]. It was also found that $\mathrm{Sp1}$, phosphorylated at Thr453 and Thr739 by ERK, binds preferentially to the reversion-inducing cysteine-rich protein with Kazal motifs (RECK) promoter, and then recruits HDAC1 to silence RECK gene expression [31]. According to these studies, phosphorylation at Thr453 and Thr739 by ERK1/2 in interphase might modulate the transactivation activity of Sp1. Taken together, the results suggest that phosphorylation of Sp1 at Thr739 is very important. In interphase cells, it affects $\mathrm{Sp} 1$ transcriptional activity by modulating different regulatory factors, such as HDAC1. In mitotic cells, Thr739 phosphorylation controls the movement of Sp1 in and out of chromosomes to finish chromosome packaging by decreasing Sp1 DNA binding affinity. Finally, it stabilizes $\mathrm{Sp} 1$ by shielding it from interaction with RNF4.

\section{Sumoylation and ubiquitination}

Sumoylation is a post-translational modification involved in various cellular processes such as nuclear-cytosolic transport, transcriptional regulation, protein stability, DNA repair, and apoptosis [40-44]. Sp1 can be sumoylated by SUMO-1 at Lys16. Sumoylation of Sp1 decreases its protein stability by altering its subcellular localization and recruiting regulatory particle triphosphatase 6 (RPT6) to increase ubiquitination. The sumoylation level of $\mathrm{Sp} 1$ is decreased in tumorous cervical tissues. These results suggest that $\mathrm{Sp} 1$ accumulation correlates with the inhibition of sumoylation during tumorigenesis [34]. In our recent study, we found that RNF4 acts as the E3 ubiquitin ligase and triggeres Sp1 sumoylation and ubiquitin-mediated proteolysis [33].

\section{Acetylation}

Acetylation of histones, especially histone $\mathrm{H} 3$ and $\mathrm{H} 4$, is important for gene regulation [45]. Recently, several important non-histone proteins, such as p53 and Sp1, were reported to be acetylated $[36,46,47]$. We found that phorbol 12-myristate 13-acetate (PMA) induces the deacetylation of Sp1, and then increases Sp1 transcriptional activity at a target gene, 12(S)-lipoxygenase, by enhancing the recruitment of p300 to the promoter of $12(S)$ lipoxygenase [36].

\section{Methylation}

Methylation, a common histone modification, negatively affects gene expression by recruiting suppressor factors such as HDACs or DNA methyltransferases [48]. Recently, the functional activity of several important transcription factors was found to be modified by methylation $[49,50]$. We recently found that methylated Sp1 recruits Suv39H1 and HDAC1 to the promoter of Sp1 target genes to repress gene expression [35]. However, the enzyme that provides the methyltransferase activity and the residue(s) that is methylated are still unknown.

\section{Glycosylation}

Many important transcription factors, including Sp1, a key promoter required for an optimal HSP response following stress, are glycosylated by the O-GlcNAc pathway [51]. Previous studies indicated that heat shock factor-1, HSP70, and HSP27 expression all rely on Sp1 binding to their promoter regions [52-54]. Exposure of either cell line to high-dose glutamine is sufficient to induce Sp1 glycosylation and regulation of its target genes, such as argininosuccinate synthetase [55]. However, under glucose starvation, stimulation with cyclic AMP (cAMP) results in nearly deglycosylation of $\mathrm{Sp} 1$, and $\mathrm{Sp} 1$ is rapidly proteolytically degraded by an enzyme that can be inhibited by specific proteasome inhibitors, lactacystin and $N$-acetyl-Lleucyl-L-leucyl-L-norleucinal (LLnL) [56]. It was reported that the chloride channel-2 (ClC-2) is induced by highly phosphorylated and highly glycosylated Sp1 [57]. In addition, high glucose (HG) concentrations can potentially stimulate the expression of genes associated with the development of diabetic nephropathy [58]. A recent report also indicated that insulin dynamically regulates calmodulin gene expression by sequential $O$-glycosylation and 
Table 2 Compounds affected Sp1

\begin{tabular}{|c|c|c|c|}
\hline Drugs & Effect on Sp1 & Cancer type & Ref. \\
\hline Oldenlandia Diffusa (OD) & Positive & Breast cancer & [61] \\
\hline Arsenic trioxide & Negative & Bladder cancer & [62] \\
\hline Celecoxib & Negative & Pancreatic cancer & [63] \\
\hline Bortezomib & Negative & Acute myeloid leukemia & [64] \\
\hline Curcumin & Negative & Bladder cancer & [65] \\
\hline GT-094 & Negative & Colon cancer & {$[66]$} \\
\hline 3,3'-diindolylmethane (DIM) & Positive & Breast cancer & [67] \\
\hline Indole-3-carbinol (I3C) & Negative & Breast cancer & {$[68]$} \\
\hline Trichostatin A (TSA) & Positive & Hepatoma & [69] \\
\hline Tolfenamic Acid & Negative & Pancreatic cancer & {$[70]$} \\
\hline Mithramycin A & Negative & ND & [71] \\
\hline Betulinic acid & Negative & Prostate and lung cancer & {$[72,73$} \\
\hline
\end{tabular}

ND: non-determine.

phosphorylation of Sp1 in liver cells [59]. In addition, hyperglycemia-induced mitochondrial superoxide overproduction increases hexosamine synthesis and $O$-glycosylation of Sp1, which activates the expression of genes that contribute to the pathogenesis of diabetic complications [60]. According to previous studies, there is a good correlation between glycosylation and phosphorylation of Sp1. Cross-talk between phosphorylation and glycosylation requires further investigation.

\section{Compounds inhibiting Sp1 transcriptional activity}

Sp1 accumulates in most of cancer types and participates in their tumorigenesis. Several compounds with anti-tumor effects act by inhibiting Sp1 transcriptional activity as indicated in Table 2. A previous study found that Oldenlandia diffusa (OD) extracts strongly inhibit anchorage-dependent and -independent cell growth and induced apoptosis in ER $\alpha$-positive breast cancer cells, and increase p53 expression as a result of enhanced binding of the ER $\alpha / \mathrm{Sp} 1$ complex to the p53 promoter region [61]. Arsenic trioxide downregulates Sp1 expression and Sp-dependent gene expression in bladder cancer [62]. Celecoxib treatment reduces both Sp1 DNA binding affinity and its transactivating activity in pancreatic cancer [63]. Bortezomib decreases Sp1 protein levels, disrupts the interaction of Sp1 with NF-kappaB, and prevents binding of the Sp1/NF-kappaB complex to the DNMT1 gene promoter for repression in acute myeloid leukemia [64]. Curcumin was reported to induce proteasome-dependent degradation of $\mathrm{Sp}$ protein in bladder cancer [65]. GT-094 could downregulate Sp expression, and then repress $\mathrm{Sp}$-regulated genes in colon cancer [66]. Treatment with 3,3'-diindolylmethane (DIM) could induce Sp1-mediated p21 expression in breast cancer cells [67]. Indole-3-carbinol (I3C) inhibits Sp1-mediated CDK6 expression in breast cancer [68].
Trichostatin A (TSA) treatment could increase Sp1mediated IGF binding protein 3 (IGFBP-3) promoter activity in hepatoma [69]. Tolfenamic acid treatment induces the degradation of $\mathrm{Sp} 1, \mathrm{Sp} 3$, and $\mathrm{Sp} 4$ in pancreatic cancer [70]. Mithramycin A, the G-C specific DNAbinding drug, could bind to both consensus sequences and then prevent subsequent Sp1 binding to repress Sp1-mediated target gene expression [71]. Betulinic acid (BA) was reported to induce Sp1 degradation in prostate cancer [72]. Our recent study also indicates that BA could induce the sumoylation of Sp1 and then recruit the E3 ubiquitin ligase, RNF4, which contains SUMOinteracting motifs, to increase Sp1 ubiquitination, leading to $\mathrm{Sp} 1$ degradation in lung cancer [73].

\section{Perspective}

Although many studies have addressed the importance of $\mathrm{Sp} 1$ in tumorigenesis, much about $\mathrm{Sp} 1$ is still unknown. First, many post-translational modifications have been identified, but the cross-talk between these modifications needs further studies. Second, although many functions have been described, the relationship between Sp1 function and structure remains unknown. This may be due to instability of the Sp1 protein. Finally, a growing number of compounds inhibit $\mathrm{Sp} 1$ and suppress tumor formation, but a detailed mechanism and the side effects require further clarification.

\section{Author details}

${ }^{1}$ Institute of Basic Medical Sciences, College of Medicine, National ChengKung University, Tainan 701, Taiwan. ${ }^{2}$ Department of Pharmacology, College of Medicine, National Cheng-Kung University, Tainan 701, Taiwan. ${ }^{3}$ Institute of Bioinformatics and Biosignal Transduction, College of Bioscience and Biotechnology, National Cheng-Kung University, Tainan 701, Taiwan. ${ }^{4}$ Center for Infection Diseases and Signal Transduction Research, National ChengKung University, Tainan 701, Taiwan. ${ }^{5}$ Graduate Institute of Medical Sciences, College of Medicine, Taipei Medical University, Taipei, Taiwan. 
Received: 25 September 2012 Accepted: 3 October 2012

Published: 14 November 2012

\section{References}

1. Dynan WS, Tjian R: The promoter-specific transcription factor Sp1 binds to upstream sequences in the SV40 early promoter. Cell 1983, 35:79-87.

2. Wierstra I: Sp1: emerging roles-beyond constitutive activation of TATAless housekeeping genes. Biochem Biophys Res Commun 2008, 372:1-13.

3. Liu YW, Arakawa T, Yamamoto S, Chang WC: Transcriptional activation of human 12-lipoxygenase gene promoter is mediated through Sp1 consensus sites in A431 cells. Biochem J 1997, 324(Pt 1):133-140.

4. Yan GZ, Ziff EB: Nerve growth factor induces transcription of the p21 WAF1/CIP1 and cyclin D1 genes in PC12 cells by activating the Sp1 transcription factor. J Neurosci 1997, 17:6122-6132.

5. Pore N, Liu S, Shu HK, Li B, Haas-Kogan D, Stokoe D, Milanini-Mongiat J, Pages G, O'Rourke DM, Bernhard E, Maity A: Sp1 is involved in Aktmediated induction of VEGF expression through an HIF-1-independent mechanism. Mol Biol Cell 2004, 15:4841-4853.

6. Chuang JY, Hung JJ: Overexpression of HDAC1 induces cellular senescence by Sp1/PP2A/pRb pathway. Biochem Biophys Res Commun 2011, 407:587-592.

7. Marin M, Karis A, Visser P, Grosveld F, Philipsen S: Transcription factor Sp1 is essential for early embryonic development but dispensable for cell growth and differentiation. Cell 1997, 89:619-628.

8. Knappskog S, Lonning PE: Effects of the MDM2 promoter SNP285 and SNP309 on Sp1 transcription factor binding and cancer risk. Transcription 2011, 2:207-210.

9. Glait C, Tencer L, Ravid D, Sarfstein R, Liscovitch M, Werner H: Caveolin-1 up-regulates IGF-I receptor gene transcription in breast cancer cells via Sp1- and p53-dependent pathways. Exp Cell Res 2006, 312:3899-3908.

10. Kim K, Thu N, Saville B, Safe S: Domains of estrogen receptor alpha (ERalpha) required for ERalpha/Sp1-mediated activation of GC-rich promoters by estrogens and antiestrogens in breast cancer cells. Mol Endocrinol 2003, 17:804-817.

11. Wietzke JA, Welsh J: Phytoestrogen regulation of a Vitamin D3 receptor promoter and 1,25-dihydroxyvitamin D3 actions in human breast cancer cells. J Steroid Biochem Mol Biol 2003, 84:149-157.

12. Varshochi R, Halim F, Sunters A, Alao JP, Madureira PA, Hart SM, Ali S, Vigushin DM, Coombes RC, Lam EW: ICl182,780 induces p21Waf1 gene transcription through releasing histone deacetylase 1 and estrogen receptor alpha from Sp1 sites to induce cell cycle arrest in MCF-7 breast cancer cell line. J Biol Chem 2005, 280:3185-3196.

13. Hsu TI, Wang MC, Chen SY, Yeh YM, Su WC, Chang WC, Hung JJ: Sp1 expression regulates lung tumor progression. Oncogene 2011.

14. Lin RK, Wu CY, Chang JW, Juan $\amalg$, Hsu HS, Chen CY, Lu YY, Tang YA, Yang YC, Yang PC, Wang YC: Dysregulation of p53/Sp1 control leads to DNA methyltransferase-1 overexpression in lung cancer. Cancer Res 2010, 70:5807-5817

15. Blaine SA, Wick M, Dessev C, Nemenoff RA: Induction of CPLA2 in lung epithelial cells and non-small cell lung cancer is mediated by Sp1 and c-Jun. J Biol Chem 2001, 276:42737-42743.

16. Wilson AJ, Chueh AC, Togel L, Corner GA, Ahmed N, Goel S, Byun DS, Nasser S, Houston MA, Jhawer M, et al: Apoptotic sensitivity of colon cancer cells to histone deacetylase inhibitors is mediated by an Sp1/ Sp3-activated transcriptional program involving immediate-early gene induction. Cancer Res 2010, 70:609-620.

17. Jungert K, Buck A, Buchholz M, Wagner M, Adler G, Gress TM, Ellenrieder V: Smad-Sp1 complexes mediate TGFbeta-induced early transcription of oncogenic Smad7 in pancreatic cancer cells. Carcinogenesis 2006, 27:2392-2401

18. Song IS, Ha GH, Kim JM, Jeong SY, Lee HC, Kim YS, Kim YJ, Kwon TK, Kim NS: Human ZNF312b oncogene is regulated by Sp1 binding to its promoter region through DNA demethylation and histone acetylation in gastric cancer. Int J Cancer 2010

19. French SW, Malone CS, Shen RR, Renard M, Henson SE, Miner MD, Wall R, Teitell MA: Sp1 transactivation of the TCL1 oncogene. J Biol Chem 2003, 278:948-955.

20. Tan NY, Khachigian LM: Sp1 phosphorylation and its regulation of gene transcription. Mol Cell Biol 2009, 29:2483-2488.
21. Fojas De Borja P, Collins NK, Du P, Azizkhan-Clifford J, Mudryj M: Cyclin ACDK phosphorylates Sp1 and enhances Sp1-mediated transcription. The EMBO journal 2001, 20:5737-5747

22. Chuang JY, Wang SA, Yang WB, Yang HC, Hung CY, Su TP, Chang WC, Hung JJ: Sp1 phosphorylation by cyclin-dependent kinase 1/cyclin B1 represses its DNA-binding activity during mitosis in cancer cells. Oncogene 2012.

23. Armstrong SA, Barry DA, Leggett RW, Mueller CR: Casein kinase II-mediated phosphorylation of the $C$ terminus of $\mathrm{Sp} 1$ decreases its DNA binding activity. J Biol Chem 1997, 272:13489-13495.

24. Tan NY, Midgley VC, Kavurma MM, Santiago FS, Luo X, Peden R, Fahmy RG, Berndt MC, Molloy MP, Khachigian LM: Angiotensin II-inducible plateletderived growth factor-D transcription requires specific Ser/Thr residues in the second zinc finger region of Sp1. Circ Res 2008, 102:e38-51.

25. Olofsson BA, Kelly CM, Kim J, Hornsby SM, Azizkhan-Clifford J: Phosphorylation of Sp1 in response to DNA damage by ataxia telangiectasia-mutated kinase. Mol Cancer Res 2007, 5:1319-1330.

26. Chun RF, Semmes OJ, Neuveut C, Jeang KT: Modulation of Sp1 phosphorylation by human immunodeficiency virus type 1 Tat. J Virol 1998, 72:2615-2629.

27. Zheng XL, Matsubara S, Diao C, Hollenberg MD, Wong NC: Epiderma growth factor induction of apolipoprotein A-I is mediated by the RasMAP kinase cascade and Sp1. J Biol Chem 2001, 276:13822-13829.

28. Chuang JY, Wang YT, Yeh SH, Liu YW, Chang WC, Hung JJ: Phosphorylation by c-Jun $\mathrm{NH} 2$-terminal kinase 1 regulates the stability of transcription factor Sp1 during mitosis. Mol Biol Cell 2008, 19:1139-1151.

29. Milanini-Mongiat J, Pouyssegur J, Pages G: Identification of two Sp1 phosphorylation sites for p42/p44 mitogen-activated protein kinases: their implication in vascular endothelial growth factor gene transcription. J Biol Chem 2002, 277:20631-20639.

30. Bonello MR, Khachigian LM: Fibroblast growth factor-2 represses plateletderived growth factor receptor-alpha (PDGFR-alpha) transcription via ERK1/2-dependent Sp1 phosphorylation and an atypical cis-acting element in the proximal PDGFR-alpha promoter. J Biol Chem 2004, 279:2377-2382.

31. Hsu MC, Chang HC, Hung WC: HER-2/neu represses the metastasis suppressor RECK via ERK and Sp transcription factors to promote cell invasion. J Biol Chem 2006, 281:4718-4725.

32. Zhang Y, Liao M, Dufau ML: Phosphatidylinositol 3-kinase/protein kinase Czeta-induced phosphorylation of Sp1 and p107 repressor release have a critical role in histone deacetylase inhibitor-mediated derepression [corrected] of transcription of the luteinizing hormone receptor gene. Mol Cell Biol 2006, 26:6748-6761.

33. Wang YT, Yang WB, Chang WC, Hung JJ: Interplay of posttranslational modifications in Sp1 mediates Sp1 stability during cell cycle progression. J Mol Biol 2011, 414:1-14

34. Wang YT, Chuang JY, Shen MR, Yang WB, Chang WC, Hung JJ: Sumoylation of specificity protein 1 augments its degradation by changing the localization and increasing the specificity protein 1 proteolytic process. J Mol Biol 2008, 380:869-885.

35. Chuang JY, Chang WC, Hung JJ: Hydrogen peroxide induces Sp1 methylation and thereby suppresses cyclin B1 via recruitment of Suv39H1 and HDAC1 in cancer cells. Free Radic Biol Med 2011, 51:2309-2318.

36. Hung JJ, Wang YT, Chang WC: Sp1 deacetylation induced by phorbol ester recruits p300 to activate 12 (S)-lipoxygenase gene transcription. Mol Cell Biol 2006, 26:1770-1785.

37. Su K, Roos MD, Yang X, Han I, Paterson AJ, Kudlow JE: An N-terminal region of $\mathrm{Sp} 1$ targets its proteasome-dependent degradation in vitro. J Biol Chem 1999, 274:15194-15202.

38. Chung SS, Kim JH, Park HS, Choi HH, Lee KW, Cho YM, Lee HK, Park KS Activation of PPARgamma negatively regulates O-GlcNAcylation of Sp1. Biochem Biophys Res Commun 2008, 372:713-718.

39. Wang SA, Chuang JY, Yeh SH, Wang YT, Liu YW, Chang WC, Hung JJ: Heat shock protein 90 is important for $\mathrm{Sp} 1$ stability during mitosis. $\mathrm{J} \mathrm{Mol} \mathrm{Biol}$ 2009, 387:1106-1119.

40. Pichler A, Melchior F: Ubiquitin-related modifier SUMO1 and nucleocytoplasmic transport. Traffic 2002, 3:381-387.

41. Nacerddine K, Lehembre F, Bhaumik M, Artus J, Cohen-Tannoudji M Babinet C, Pandolfi PP, Dejean A: The SUMO pathway is essential for nuclear integrity and chromosome segregation in mice. Dev Cell 2005, 9:769-779. 
42. Lyst MJ, Stancheva I: A role for SUMO modification in transcriptional repression and activation. Biochem Soc Trans 2007, 35:1389-1392.

43. Bergink S, Jentsch S: Principles of ubiquitin and SUMO modifications in DNA repair. Nature 2009, 458:461-467.

44. Geoffroy MC, Hay RT: An additional role for SUMO in ubiquitin-mediated proteolysis. Nat Rev Mol Cell Biol 2009, 10:564-568.

45. Grunstein M: Histone acetylation in chromatin structure and transcription. Nature 1997, 389:349-352.

46. Zhao Y, Lu S, Wu L, Chai G, Wang H, Chen Y, Sun J, Yu Y, Zhou W, Zheng Q, et al: Acetylation of p53 at lysine $373 / 382$ by the histone deacetylase inhibitor depsipeptide induces expression of p21(Waf1/Cip1). Mol Cell Biol 2006, 26:2782-2790.

47. Waby JS, Chirakkal H, Yu C, Griffiths GJ, Benson RS, Bingle CD, Corfe BM: Sp1 acetylation is associated with loss of DNA binding at promoters associated with cell cycle arrest and cell death in a colon cell line. $\mathrm{Mol}$ Cancer 2010, 9:275.

48. Zhang Y, Reinberg D: Transcription regulation by histone methylation: interplay between different covalent modifications of the core histone tails. Genes Dev 2001, 15:2343-2360.

49. Chuikov S, Kurash JK, Wilson JR, Xiao B, Justin N, Ivanov GS, McKinney K, Tempst P, Prives C, Gamblin SJ, et al: Regulation of p53 activity through lysine methylation. Nature 2004, 432:353-360

50. Yamagata K, Daitoku H, Takahashi Y, Namiki K, Hisatake K, Kako K, Mukai H, Kasuya Y, Fukamizu A: Arginine methylation of FOXO transcription factors inhibits their phosphorylation by Akt. Mol Cell 2008, 32:221-231.

51. Ozcan S, Andrali SS, Cantrell JE: Modulation of transcription factor function by O-GlcNAc modification. Biochim Biophys Acta 2010, 1799:353-364

52. Oesterreich S, Hickey E, Weber LA, Fuqua SA: Basal regulatory promoter elements of the hsp27 gene in human breast cancer cells. Biochem Biophys Res Commun 1996, 222:155-163.

53. Porter W, Wang F, Wang W, Duan R, Safe S: Role of estrogen receptor/Sp complexes in estrogen-induced heat shock protein 27 gene expression. Mol Endocrinol 1996, 10:1371-1378.

54. Bevilacqua A, Fiorenza MT, Mangia F: A developmentally regulated GAGA box-binding factor and $\mathrm{Sp} 1$ are required for transcription of the hsp70.1 gene at the onset of mouse zygotic genome activation. Development 2000, 127:1541-1551.

55. Brasse-Lagnel C, Fairand A, Lavoinne A, Husson A: Glutamine stimulates argininosuccinate synthetase gene expression through cytosolic $\mathrm{O}$ glycosylation of Sp1 in Caco-2 cells. J Biol Chem 2003, 278:52504-52510.

56. Han I, Kudlow JE: Reduced O glycosylation of Sp1 is associated with increased proteasome susceptibility. Mol Cell Biol 1997, 17:2550-2558.

57. Vij N, Zeitlin PL: Regulation of the CIC-2 lung epithelial chloride channel by glycosylation of SP1. Am J Respir Cell Mol Biol 2006, 34:754-759.

58. Goldberg HJ, Whiteside Cl, Hart GW, Fantus IG: Posttranslational, reversible O-glycosylation is stimulated by high glucose and mediates plasminogen activator inhibitor-1 gene expression and Sp1 transcriptional activity in glomerular mesangial cells. Endocrinology 2006, 147:222-231.

59. Majumdar G, Harrington A, Hungerford J, Martinez-Hernandez A, Gerling IC, Raghow R, Solomon S: Insulin dynamically regulates calmodulin gene expression by sequential o-glycosylation and phosphorylation of sp1 and its subcellular compartmentalization in liver cells. J Biol Chem 2006, 281:3642-3650.

60. Du XL, Edelstein D, Rossetti L, Fantus IG, Goldberg H, Ziyadeh F, Wu J, Brownlee M: Hyperglycemia-induced mitochondrial superoxide overproduction activates the hexosamine pathway and induces plasminogen activator inhibitor-1 expression by increasing Sp1 glycosylation. Proc Natl Acad Sci U S A 2000, 97:12222-12226.

61. Gu G, Barone I, Gelsomino L, Giordano C, Bonofiglio D, Statti G, Menichini F, Catalano S, Ando S: Oldenlandia Diffusa extracts exert antiproliferative and apoptotic effects on human breast cancer cells through ERalpha/ Sp1-mediated p53 activation. J Cell Physiol 2011

62. Jutooru I, Chadalapaka G, Sreevalsan S, Lei P, Barhoumi R, Burghardt R, Safe S: Arsenic trioxide downregulates specificity protein (Sp) transcription factors and inhibits bladder cancer cell and tumor growth. Exp Cell Res 2010, 316:2174-2188.

63. Wei D, Wang L, He Y, Xiong HQ, Abbruzzese JL, Xie K: Celecoxib inhibits vascular endothelial growth factor expression in and reduces angiogenesis and metastasis of human pancreatic cancer via suppression of Sp1 transcription factor activity. Cancer Res 2004, 64:2030-2038.

64. Liu S, Liu Z, Xie Z, Pang J, Yu J, Lehmann E, Huynh L, Vukosavljevic T, Takeki $\mathrm{M}$, Klisovic RB, et al: Bortezomib induces DNA hypomethylation and silenced gene transcription by interfering with Sp1/NF-kappaBdependent DNA methyltransferase activity in acute myeloid leukemia. Blood 2008, 111:2364-2373.

65. Chadalapaka G, Jutooru I, Chintharlapalli S, Papineni S, Smith R 3rd, Li X, Safe S: Curcumin decreases specificity protein expression in bladder cancer cells. Cancer Res 2008, 68:5345-5354.

66. Pathi SS, Jutooru I, Chadalapaka G, Sreevalsan S, Anand S, Thatcher GR Safe S: GT-094, a NO-NSAID, inhibits colon cancer cell growth by activation of a reactive oxygen species-microRNA-27a: ZBTB10-specificity protein pathway. Mol Cancer Res 2011, 9:195-202.

67. Hong C, Kim HA, Firestone GL, Bjeldanes LF: 3,3'-Diindolylmethane (DIM) induces a $\mathrm{G}(1)$ cell cycle arrest in human breast cancer cells that is accompanied by Sp1-mediated activation of p21(WAF1/CIP1) expression. Carcinogenesis 2002, 23:1297-1305.

68. Cram EJ, Liu BD, Bjeldanes LF, Firestone GL: Indole-3-carbinol inhibits CDK6 expression in human MCF-7 breast cancer cells by disrupting Sp1 transcription factor interactions with a composite element in the CDK6 gene promoter. J Biol Chem 2001, 276:22332-22340.

69. Choi HS, Lee JH, Park JG, Lee Yl: Trichostatin A, a histone deacetylase inhibitor, activates the IGFBP-3 promoter by upregulating Sp1 activity in hepatoma cells: alteration of the Sp1/Sp3/HDAC1 multiprotein complex. Biochem Biophys Res Commun 2002, 296:1005-1012.

70. Abdelrahim M, Baker $\mathrm{CH}$, Abbruzzese $\mathrm{L}$, Safe S: Tolfenamic acid and pancreatic cancer growth, angiogenesis, and Sp protein degradation. J Natl Cancer Inst 2006, 98:855-868.

71. Blume SW, Snyder RC, Ray R, Thomas S, Koller CA, Miller DM: Mithramycin inhibits SP1 binding and selectively inhibits transcriptional activity of the dihydrofolate reductase gene in vitro and in vivo. J Clin Invest 1991, 88:1613-1621.

72. Chintharlapalli S, Papineni S, Ramaiah SK, Safe S: Betulinic acid inhibits prostate cancer growth through inhibition of specificity protein transcription factors. Cancer Res 2007, 67:2816-2823.

73. Hsu TI, Wang MC, Chen SY, Huang ST, Yeh YM, Su WC, Chang WC, Hung JJ: Betulinic acid decreases Sp1 level via increasing the sumoylation of Sp1 to inhibit lung cancer growth. Mol Pharmacol in press 2012.

doi:10.1186/1423-0127-19-94

Cite this article as: Chang and Hung: Functional role of post-

translational modifications of Sp1 in tumorigenesis. Journal of Biomedical Science 2012 19:94.

\section{Submit your next manuscript to BioMed Central and take full advantage of:}

- Convenient online submission

- Thorough peer review

- No space constraints or color figure charges

- Immediate publication on acceptance

- Inclusion in PubMed, CAS, Scopus and Google Scholar

- Research which is freely available for redistribution 